\title{
Effective E-government Management Mechanisms: Conceptual Approaches
}

\author{
Rasim Alguliev, Farhad Yusifov* \\ Institute of Information Technology, Baku, Azerbaijan \\ *Corresponding author: farhadyusifov@gmail.com
}

Copyright (C 2013 Horizon Research Publishing All rights reserved.

\begin{abstract}
Principals of development of e-government formation and management mechanisms are researched. Application of web-technologies and social networks in administration of e-government is reviewed. Approaches related to transformation of government administration are analyzed and feedback mechanisms are proposed for effective management of e-government.
\end{abstract}

Keywords e-government, public administration, social networks, web analytics, meritocracy, IQ

\section{Introduction}

Currently modern information technologies are widespread in developed countries and their application in actual practice is demonstrating its effect on social development of the countries. Number of users, centers and institutes that have internet access and are benefiting from it for meeting their needs is rapidly growing. In these conditions, there is an increasing necessity for mobility of transparency and political neutrality principals of government services. It must be noted that, there are currently broadening usage capabilities of political and social technologies in political administration.

E-government programs implemented in several countries form the basis of applied changes. By enabling the broadening of government services, use of e-government -ICT provides mutual information exchange of citizens, business sector and other government structures [1].

European commission continually actively supports realization of e-government projects and determination of perspectives either on national or international level. European commission has accepted several programs in order to implement e-government strategy, and has taken relevant actions [2-5].

All over the world governments are investing vast amounts of capital on implementation of e-government projects for further improvement of services rendered to citizens by governments and reducing expenses $[2,4,6]$.
Governments can increase the effectiveness of their operations and implements administrative operations more easily using ICT. Considering this important fact, processing of researches conducted in e-government development direction, also, determination and research of the most successful applied models, as well as effective administration mechanisms is quite important [6-11].

While reviewing e-government programs carried out in different countries throughout the world, it is clear that, shortly, e-government will be more accessible and effective based on "single window" principle in near future. This is mainly related to rapid development of content analysis methods, web technologies and social networks. From this standpoint, processing of effective management mechanisms in implementation of e-government projects is quite an important issue.

Application of web content mining, web-analytics and social networks is a strong asset for improvement of e-government management effectiveness and creation of feedback mechanism. Considering that formation of effective administration policy is one of the important issues for implementation of e-government programs, then application of especially new technologies significantly broadens the political communication capabilities. This allows achieving new integration forms among government, business sector and citizens.

Web analytics as a feedback mechanism

Increasing role of information and information technologies leads to development of e-democracy, information economy, e-government, e-governance, digital markets etc, i.e. concept of information society implicates method of conduction of information aspects of government actions. Realization of electronic government concept implicates integration of many functional elements, including local administration institutions.

Within the framework of growing informatization of government administration, provision of accessible information to population and business is one of the most important functions of local administration institutions. Provision of information services is carried out through development and competent support of web-site of local 
administration institution [6,12-15]. Multiple problems of sphere of local administration institutions' web-sites stipulate relevance of scientific research in this field.

Web-analytics - is monitoring of web site operation, based on which audience of visitors is determined and behavior of web- audience is studied for making decisions on development and expansion of functional capabilities of web-resource [14].

Application of web-analytics methods is necessary for many aspects of site development, such as $[14,15]$ :

- Development of functionality of the site based on tendencies in behavior of visitors;

- Evaluation of effectiveness of internet-marketing;

- Detection of problematic points in information architecture, design and content of site.

- Formulation of recommendations for improvement of resource and relevant optimization.

Web-analytics includes following methods: website traffic analysis; usability analysis, visitor behavior analysis; benchmarking; expert evaluation.

Effective web analytics - is detailed analysis of behaviors and navigations of users on a web-site and portal. It is impossible to make measures regarding optimization of a site without a precise knowledge of what users do on the site [14, 16-18]. Optimization and administration of web resources is an important condition for adaptation of a site in accordance with demands of users and citizens.

Effective web analytics of sites and portals of government institutions, as well as web sites rendering online service to citizens, is discovering of existing program, technical, content errors and their adaptation to requirements of citizens, users [19-21]. It's possible to determine the reason users leave the web site, generally behavior of users related to site or web-sites of a certain service using web analytics. It is clear that, web analytics are not limited to certain statistics, and allow to obtaining more detailed information for analysis [18, 21-23].

Traffic of departments and web-pages of a site allows understanding following [14,16,18-23]:

- Quantity of browsed web-pages,

- Keywords and phrases which visitors use to find the site in search systems.

- Geography of visitors,

- Time, spent on the web-page by visitor,

- Passages between web-pages,

- Audience of the site (accidental, permanent visitors etc)

- Site navigation convenience for visitors etc;

Considering international experience, it is proposed to develop the state programs action plan carried out in the Republic of Azerbaijan in two stages, in order to form an e-government indicator system for execution of e-government program. Due to execution of this conceptual approach, duties and responsibilities of each government administration institution in ICT field is clear, digital divide are brought to a minimum as a result of application of ICT in government sector, conduction of monitoring are facilitated, it is possible to develop more effective main action plans in the future by conducting comparative analysis. In its turn, this will allow to create bases for evaluation of formation and development (dynamics) of an e-government, process indicators on fields and administrative districts, and create a monitoring system based on that. E-government portal, sites of different government institutions, as well as web sites rendering government services can be analyzed using web analytics, deficiencies can be determined and relevant strategies can be carried out by learning demands of citizens. Also, it must be noted that, processing of technologies of decision making in online environment, studying public opinions, conductions of referendums and elections, as well as creation of situation center for each institution included in e-government are one of the quite important issues. Considering that such situation centers are created based on computers, development of mutual connection among them in accordance with safety policy requirements can be considered as one of the most important duties.

Analysis of log files collected from servers and information collected from e-mails during development of on-line connections of citizens with administration institutions plays an important role while making effective decisions by subjects of e-government as a result of use of web-analytics. In its turn, this allows operation of feedback mechanisms for management of e-government.

Social networks as a government administration mechanism

Social networks (SN) form an integral part of our lives, uniting people with common interests in internet-environment. Currently virtual networks supporting technology such as blogs and Wiki compose the majority of web-sites.

Let's note that, term SN is currently often used in sociology. Network modeling of social processes represents private philosophy for data analysis. In its turn, this allows uniting different mathematical approaches, statistics, system analysis, imitation models in single organism for solution of social tasks. Network analysis facilitates modeling of structural interrelation among social individuals, people, staffs or organization [24, 25]. In relation to this, let's note that, SN analysis if currently widely used in economics, management, medicine, criminology and other fields.

Currently, development and sufficient popularization of $\mathrm{SN}$ among users promotes their use in different field. From this standpoint, application of SN during the process of creation and management of e-government is one of the relevant issues of our day. Application of $\mathrm{SN}$ in processes of creation of information society, as well as transformation and development of government administration mechanisms allows developing effective solution methods.

Position of users is determined during the process of web analysis, which has a special value for determination of their role in the network. Several principal stages can be demonstrated during the process of web analysis. Each stage solves its specific methodological task. Firstly, indicators characterizing specifics of network connections are developed. Based on that, a survey is created for network 
users. Collected data is analyzed and the network is established. Methods measuring Indicators, reflecting the structural characteristics of the network are developed on the next stage.

In such manner, $\mathrm{SN}$ is considered as the key element for consecutive development of the society, and shortly they will become an inseparable part of any activity sphere.

Multiple general-director or niche social services occur every year, and active users of Internet typically have several profiles in different social networks. Discovering profiles, belonging to the same person, in several social networks, allows to obtain more complete social graph, which can be useful in many tasks, such as information search, effective administration, recommendation systems etc.

The most significant work for user identification is [26], which represents many heuristics using information on profiles, as well as connections among them. Similar researches are described in [25, 27-29]. In [27] compared a couple of profiles between the "Facebook" network and "MySpace", in its turn [25] solved the analogical task for "Twitter" and "EntityCube". In [28] in their research generated accidental social graphs with accidentally formed profiles and applied multiple complex heuristics to them, in order not to miss a single potentially useful information source, accessible in social network. In the work of [29], profiles from "Facebook" and "StudiVZ" are presented as vectors of factors, to which subsequently operations of precise, partial and fuzzy comparison were applied to, and identification was carried out in accordance with their results.

Application of SN in conducted researches is considered as a new direction for effective e-government management, which is based on results on analysis of massive e-documents and monitoring of information environment. Proposals for adoption of administrative solutions are formed on data analysis level and based on obtain information; and conclusion is provided. Decision making in accordance with obtained information is the conclusive stage after report preparation based on feedback as a result of conduction of evaluation measures.

Meritocracy and transformation of government administration

Significant changes have taken place in the world during the last semi centenary. It is impossible to imagine the mere existence of modern society without development of scientific researches, introduction and improvement of new technologies. All this sets high demands for qualification of skilled personnel. Level of scientific researches and introduction speed of obtained results determine the potential of the government in many ways.

Initial theoretical expressions about production characteristics of expenses spent on development of capabilities of the population towards labor were established by W.Petty, A.Smith, D.Ricardo and et al. In XX century, given direction in economy was developing in the works of F.Machlup, M.Blaug, G.Becker, L.Walras, A.Marshall, T.Schultz, J.Mincer, I.Fisher,. Research of issues related to investment in human capital, conditions of its formation and accumulation are broadly presented in the works of western economists W.Baumol, J.Stiglitz, R.Masgrave, P.Samuelson and et al.

Transition to information society leads to necessity of researches of categories such as "intellectual potential" and "intellectual capital". Research of given problem is presented in works of authors T.Parkinson, D.Bell, L.Edwinson, E.Brooking, and others.

Intellectual potential of the society is formed and developed by systems of upbringing, education, skills upgrading and retraining of staff, self-education, science, researches and developments, as well as using methods, means, instruments and mechanisms which are applied upon making and realization of decisions in different fields $[30,31]$.

Intellectual potential of the society, regions, branches, enterprises, organization depends on their mission, strategy, targets and tasks, which they set forth themselves and affects them. For this reason intellectual potential of the society must necessarily be reviewed not only in short-term, but also in average-term and long-term periods.

Besides, intellectual potential of the society is connected with cultural level. High level of culture promotes growth of intellectual potential, low level, accordingly promotes its decreasing.

Rapid development of Information Society nowadays, is turning determination of Intelligence quotient (IQ) of citizens in the future into an important issue [31-34]. Initiatives of this nature already exist and such services rendered on Internet. Upon employment, intelligence indicators are also required from people.

Equally, expressing voters' regards on different matters during election process, definition of public opinion by generalizing results, continuous conduction of these processes are among capabilities provided by e-democracy $[35,36]$. At the same time, development of test programs reflecting regards to certain issues and problems in different situations in order to at least partially define the quality of elected ones (intellectual level) enables to conduct evaluation on several indicators.

Based on organization of discussion of pre-election platforms of candidates in social networks, reflection of IQ of citizens on e-maps, visualization of IQ-geography of citizens by country etc enables to conduct different analysis based on abovementioned and make efficient decisions [33, $34,37,38]$.

In 1958, Britain sociologist Michael Young, described such futuristic society in his book titled "The Rise of Meritocracy, 1870-2033", where management of the society is carried out based on IQ-indicators of people [39]. American sociologist Daniel Bell, noted in his book titled "Coming of Post-industrial Society" in 1973, that in near future meritocracy will eliminate bureaucracy and social structure of the society will change [40].

Meritocracy underlines the equality of rather competition, than the result, establishing that, position in a professional 
hierarchy is taken due to merits in accordance with universal, objective criteria, not in accordance with accredited merits such as age, gender, race or inherited wealth [30-33, 35, 41]. Not a single person - deserving, competent or of relevant character - cannot be denied the opportunity to reach a commensurate social status. The basis of given idea - is confidence that, there is only a limited number of talents and the most important function of the education system is to trace that they are not wasted, but developed and consolidated [31, 33, 41]. Opponents prove that, true equality can be achieved only by adopting policy directed at creation of larger equality as a final result of the system, but not at the starting point.

Currently meritocracy problems are earnestly researched by leading scientific centers. Conducted researches provide grounds to state that, e-democracy will provide transformation from ochlocratic democracy to meritocratic democracy.

Representative democracy is a democracy of a certain place and time (elections are carried out at certain periods). Direct democracy does not depend on place and time, it is in action at all times and places (for example: Wikidemocracy, social networks etc). This means that citizens must participate in e-government formation and administration, regardless of the country.

Quality (intellectual level) of candidates in e-government depends of quality (intellectual level) of voters. As organization of election process in agrarian and industrial societies faces significant organizational, financial and other problems, there was to alternative to democracy based on quantity due to reasons such as difficulties in spreading information and interactive relations among candidates and voters. Quantity based democracy assumed the age and address of the voter as the basis, i.e. parameters characterizing his intellect and mentality were not considered. Briefly, votes of the voters were not differentiated.

In knowledge society, the result of the election can be calculated by considering general intellect of voters and candidates. Thus, possession of more votes by voters with higher intellectual coefficient in comparison to voters with lower intellectual coefficient is an alternative with possible application.

Here it must be noted that, there are several existing tests, methods etc for calculation of intelligence quotients (IQ) of people [34, 37, 38, 42]. Psychometrics science is recently rapidly developing and can posses significant capabilities related to this issue in the future. Scientists research people's IQ based on their gender, occupation, country, nationality, continent, relation, race etc factors, analyze the results, detect their mutual relation to other social-economical, geographical parameters.

Conclusion

Large-scale reforms directed at increasing the effectiveness of government management have been conducted in many countries of the world during last several decades. It is not accidental that "Management revolution" expression has received practically simultaneous transformations. The search of new approaches to organization of public administration system has lead to refusal from traditional type of management rationalization, actualization of self-organization processes and self-management of social systems, as well as increasing of social effectiveness of government management.

In implementation of e-government projects processing of effective management mechanisms is an important issue. Web content analysis methods, application of web-technologies and social networks enable to improve e-government management effectiveness and create feedback mechanisms.

During Information Society formation, implementation of large scale e-government programs makes processing of new management mechanisms for regulation of government-citizen relations on the highest level, necessary. As the information society develops, transition from democracy based on quantity (ochlocracy) to democracy based on quality (meritocracy) will be carried out.

Proposed given approaches such as feedback mechanism for increasing the effectiveness of government management is mainly concentrated on high efficiency of public administration, political pluralism in decision making process, delegation of authority to lower levels of administration hierarchy, more balanced power distribution, responsibility and accountability, development and broadening of citizen participation.

\section{REFERENCES}

[1] ICT for Public Services. European Commission, https://ec.europa.eu/digital-agenda/en/ict-public-services

[2] European eGovernment Action Plan 2011-2015. European Commission,

https://ec.europa.eu/digital-agenda/en/e uropean-egovernment-action-plan-2011-201 $\underline{5}$

[3] i2010 - A European Information Society for growth and employment. European Commission, Information Society, http://ec.europa.eu/information society/eeurope/i2010/index en.htm

[4] Europe 2020: A strategy for smart, sustainable and inclusive growth, European Commission. Information Society, http://ec.europa.eu/europe2020/index en.htm

[5] The new Interoperability Solutions for European Public Administrations (ISA), ec.europa.eu/isa/

[6] United Nations E-Government Survey 2012, http: / / www2 .unpan.org/egovkb/global reports/12report.htm

[7] Johnson, O.A., King, S.F.: Best Practice In Local 
E-Government: A Process Modelling Approach. In: Proceedings of the e-Government Workshop '05 (eGOV05). Brunel University, West London (2005)

[8] Seifert, J.W., McLoughlin, G.J.: State E-Government Strategies: Identifying Best Practices and Applications (2007), http: //www. fas.org/sgp/crs/secrecy/RL34104.pdf

[9] Rabaiah, A., Vandijck, E.: A Strategic Framework of e-Government: Generic and Best Practice (2009), www.ejeg.com/issue/download.html?idArtic $1 e=196$

[10] E-Governance And Best Practices, http://digitalknowledgecentre.in/files/2012/02/e-Governance-and-best-prac tices.pdf

[11] Alhomod, S.M. and Shafi, M.M.: Best Practices in E government: A review of Some Innovative Models Proposed in Different Countries. In: International Journal of Electrical \& Computer Sciences, vol. 12, No 01, pp.1-6 (2012)

[12] Wenhua, X., Jian, Y.: E-government and the change of government management mode. In: International Conference on E-Business and E-Government, pp. 675-678 (2010)

[13] Fong, S., Meng, H.S.: Web-based Performance Monitoring System fore-Government Services. In: ICEGOV2009, Bogota, Colombia,

http://www.sftw.umac.mo/ ccfong/pdf/ simonfong 2009 icegov wms.pdf

[14] Kaushik, A.: Web Analytics 2.0 - The Art of Online Accountability and Science of Customer Centricity, $447 \mathrm{p}$. Wiley Publishing, Inc. (2010)

[15] Web Analytics Association, http://www.webanalyticsassociation.org/

[16] Cooley, R.: The Use of Web Structure and Content to Identify Subjectively Interesting Web Usage Patterns. In: ACM Transactions on Internet Technology, vol. 3, No 2, p. 93-116 (2003)

[17] Baglioni, M., Ferrara, U., Romei1, A., Ruggieri, S., and Turini, F.: Preprocessing and Mining Web Log Data for Web Personalization. In: Proccedings of the $8^{\text {th }}$ Congress of the Italian Association for Artificial Intelligence, September 23-26, vol. 2829, pp. 237-249. Pisa, Italy (2003)

[18] Balog, K., Hofgesang, P.I., Kowalczyk, W.: Modeling Navigation Patterns of Visitors of Unstructured Websites. In: Proccedings of the Twenty-fifth SGAI International Conference on Innovative Techniques and Applications of Artificial Intelligence. Springer Verlag (2005) http://www.cs.vu.nl/ci/DataMine/DIANA/pages eng/publications.html

[19] Liu, H., Keselj, V.: Combined mining of web server logs and web contents for classifying user navigation patterns and predicting users' future requests. In: Data and Knowledge Engineering, vol. 61, No 2, p. 304-330 (2007)

[20] Everts, J., Bulacu, M.: Assignment: Clustering of Web Users. Groningen University, Netherlands, (2005) http://www.ai.rug.nl/ki2/assignments/ki2 -assig03.pdf

[21] Wanga, X., Abraham, A., Smitha, K.A.: Intelligent web traffic mining and analysis. In: Journal of Network and Computer Applications, vol. 28, p.147-165 (2005)

[22] Smith, K., Ng, A.: Web page clustering using a self-organizing map of user navigation patterns. In: Decision Support Systems, vol.35, No 2, p. 245-256 (2003)

[23] Qiu, F., Cho, J.: Automatic identification of user interest for personalized search. In: Proccedings of the $15^{\text {th }} \mathrm{WWW}$ Conference (WWW15), 23-26 May, p. 727-736, Edinburgh, Scotland (2006)

[24] 2 Bouquet, P., Bortoli, S.: Entity-centric Social Profile Integration. In: Proceedings of the International Workshop on Linking of User Profiles and Applications in the Social Semantic Web (LUPAS 2010), pp. 52-57 (2010)

[25] 4 Gae-won, Y., Seung-won, H., Zaiqing, N., Ji-Rong, W.: SocialSearch: Enhancing Entity Search with Social Network Matching. EDBT, (2011) http://ids.postech.ac.kr/papers/socialse arch.pdf

[26] Veldman, I.: Matching Profiles from Social Network Sites. Master's thesis, University of Twente, essay.utwente.nl/59436/1/scriptie I Veld man.pdf

[27] Motoyama, M., Varghese, G.: I Seek You - Searching and Matching Individuals, In: Social Networks. WIDM '09: Proceeding of the eleventh international workshop on Web information and data management, http: //cseweb. ucsd.edu/ mmotoyam/widm09-iseekyou.pdf

[28] Raad, E., Chbeir, R., Dipanda, A. User Profile Matching in Social Networks. In: $13^{\text {th }}$ International Conference on Network-Based Information Systems (NBiS), (2010) http://hal.archives-ouvertes.fr/docs/00/ 64/35/09/PDF/User Profile Matching in Social Networks.pdf

[29] Vosecky, J., Dan Hong, Shen, V.Y.: User identification across multiple social networks. In: Proccedings of First International Conference on Networked Digital Technologies (2009)

[30] Gardner, H.: Frames of mind: The theory of multiple intelligences. 440 p. New York: Basic Books, USA (1983)

[31] Hunt, E.: The role of intelligence in modern society. In: American Scientist. vol. 83, p. 356-368 (1995) http://www.psych.utoronto.ca/users/reingold/courses/intelligence/cache/Hunt-full.html

[32] Herrnstein, R.J., Murrey, Ch.: The bell curve: Intelligence and class structure in American life. 845 p., New-York: Free Press, (1994)

[33] Hunt, E., Wittmann, W.: National intelligence and national prosperity, In: Intelligence, A Multidisciplinary Journal, vol. 36, no 1, pp.1-9 (2008)

[34] Kanazawa, S.: IQ and the wealth of states. In: Intelligence, A Multidisciplinary Journal, vol. 34. pp. 593-601 (2006)

[35] Meier, A.: eDemocracy \& eGovernment. Springer-Verlag. Berlin, Heidelberg (2012)

[36] Hilbert, M.: The Maturing Concept of E-Democracy: From 
E-Voting and Online Consultations to Democratic Value Out of Jumbled Online Chatter. In: Journal of Information Technology \& Politics, vol. 6, pp. 87-110 (2009)

[37] Weiss, V. National IQ Means, Calibrated and Transformed from Educational Attainment, and Their Underlying Gene Frequencies. In: Mankind Quarterly, vol. 49, pp. 129-164 (2008)

http://www.v-weiss.de/calibration.html

[38] McDaniel, M.A.: Estimating state IQ: measurement challenges and preliminary correlates. In: Intelligence, A Multidisciplinary Journal, vol. 34, pp. 607-619 (2006)

[39] Young, M.: The rise of the meritocracy, 1870-2033: An essay on education and inequality, $160 \mathrm{p}$. Thames \& Hudson, London (1958)

[40] Bell, D.: “On meritocracy and equality", National Affairs. Public Interest, vol. 29, pp. 29-68 (1972) http: //www.nationalaffairs.com/doclib/20 0805271972029020 nmeritocracyandequalitydanielbell.pdf

[41] Daniels, N.: "Merit and meritocracy", Philosophy \& Public Affairs, vol. 7, No. 3, Spring, pp. 206-223 (1978)

[42] Irwing, P., Lynn, R.: The relation between childhood IQ and income in middle age. In: Journal of Social, Political and Economic Studies. vol. 31. pp.191-196 (2006) 